\title{
Assembly line balancing in an electronics company using simulation approach
}

\author{
Khalida Syahputri ${ }^{1 *}$, Jelly Leviza ${ }^{1}$, Sari Sari ${ }^{1}$, Indah Rizkya $\mathrm{T}^{1}$, Humala Napitupulu ${ }^{1}$, and Anizar Anizar ${ }^{1}$ \\ ${ }^{1}$ Universitas Sumatera Utara, Department of Industrial Engineering, Faculty of Engineering, Medan, Indonesia
}

\begin{abstract}
One of the efforts company did continuously to compete was to reduce waste or anything that is not adding value to products such as waiting activity that cause unbalance of workload between workstations on a production path. This condition resulted in idle work station, accumulation of intermediate goods, and low work station utility. Companies finds an unbalance workload. This work station are apparently have to wait in a given time after workstations does behind it finished. For that reason, this study aims to balance the workload between workstations and increase the company production capacity. This research uses simulation approach by modelling the initial production with software promodel and evaluate performance the the initial production with an indicator current content, output, and average time in operation. The performance of the initial production line model was the smoothness index of 2007.5, the current content of 10 units, the output of 34 units, and the average time in operation of 35.19 minutes. The alternative model of the selected production trajectory is due to excel in four track performance factors is lowest current content (1 unit), highest output (48 units), lowest smoothness index $(461,8)$ and highest production capacity $(9,12$ unit / hour $)$.
\end{abstract}

\section{Introduction}

The ever-increasing growth in the manufacturing industry has trigerred companies to look for ways to stay competitive. One effort made by minimizing idle activity that has no added value to the product. Unemployment activity occurs because of unbalance workload between workstations in the production path. This activity resulted in the accumulation of raw materials to be processed on a particular work station (bottleneck).

Problems that occur in the electronics company making the fan is the amount of stacking in some work stations. The company has 9 work stations where the highest accumulation occurs at the packing station. This is because at the packing station requires a longer processing time compared to other work stations. Therefore, it is necessary to analyze the track balance from the production line so that the production process will run smoothly.

Assembly line balancing is the process of allocating a group of tasks to be performed on an ordered sequence of workstations in such a manner that all workstations have approximately equal allotted time to finish their tasks [1]. Assembly lines balancing used to attain operations needed during product formation at assembly stations in the way that the duration of lost time can be reduced. In other words it is described as allocating work pieces to operation systems [2][3]. The main objective of the assembly line balancing is the minimization of idle time in the line production and consequently improving the assembly line production efficiency by minimize the number of required workstations, cycle time, or a combination of both[4]. There are some indicators used to determine the quality of line balancing, line efficiency, smoothing index and time of linebalancing [5][6].

The problem of track balance can generally besolved by heuristic and analytic (mathematical) methods. However, the results obtained from both methods are not able to predict or analyze the performance of the results if applied to actual conditions. Therefore, a [7] simulation approach is required to analyze the performance of the alternatives produced without having to wait to beapplied first to the real system.

Simulation is an important tool to analyse the current situation and determine what is necessary to be done later on. Simulation also has important advantages in foreseeing the results of the investment decision while a company is determining investments and in enabling to make a choice between the two current situations [2]. Process simulation allows management to study the dynamics of the business and to consider the effects of changes without risk. With simulation models, we can explore how an existing system might perform if altered, or how a new system might behave before the prototype is even completed, thus saving on costs [8]. Simulations using a computer to evaluate a model numerically over a certain period and data are collected to estimate the real desired characteristics of a model [9]

Many research about assembly line balancing using simulation has been conducted in many different industrial areas. [10] Line balancing performed a

\footnotetext{
*Corresponding author: syahputri.khalida@,gmail.com
} 
simulation to evaluate the impact ofreduction of the cycle time on the throughput and machine utilization studied in an automated cylinder block production transfer line. [11] A simulation model was created an assembly line balancing method based on genetic algorithm in gear-box production system. [12] Simulation of assembly line balancing also has studied in an automotive component in a vendor manufacturing company. [13] Assembly line balancing using simulation in garment production has conducted to determine the bottlenecks in the line and then tried four possible scenarios that were formed by various what-if analyses in order to balance line as well as to increase its efficiency.

In the previous research, researchers have attempted to balance assembly lines in many different areas by using simulation [14]. However, research on the assembly line balancing using simulations has never been done with electronics companies. The purpose of this study is balance the workload between workstations in fan production by simulation and increase company production capacity.

\section{Methodology}

The study was conducted on the production of household electronic appliances such as fan products. The study uses activities to develop the production line.

Firstly, describe workflow and time study along the line in detail. Then, made a precedence diagrams based on sequence of processes on the line production and calculated a smoothing index for the actual line production. The next step, analyze the actual system by simulation model. Simulation will be done using ProModel 7.5 Student Version software. [15] The simulation using this software is done with several stages, that is problem formulation, model translation, verified, validated, experimental design, and production run and analysis. Problem formulation is the first stage in building a simulation model. At this stage determined the problems that occur, the purpose of simulation design.

After problem and destination statements are defined at this stage, then the model translation is performed. Before translating the model, first the distribution pattern of the data that is the main input of the simulation is determined. Translation model aims to translate the system into a computer program that will be used to analyze system problems. Model translation is done after using ProModel 7.5 Student Version software. After the model of the production path of the fan is obtained when the translation of the model with ProModel 7.5 Student Version software, then verified to ensure that the computer program has been compiled accordingly and correctly.

Then validate the model to see the accuracy of the results of the simulation. Experiments were then conducted by determining alternatives to the early model system of the fan production trajectory. [16] The determination of alternatives is done with the basic rules of balancing the production trajectory of split the task (giving the workpiece of a work station to the next work station by not exceeding the cycle time) and sharing the task (the division of work stations that have an operating time over time cycle into two or more work stations). After improvement alternatives are obtained, the next step is to simulate each alternative model. The simulation results of each alternative are analyzed by looking at the criteria of output, current content, and average time in operation which is a track performance factor in ProModel.

According to simulation results, alternative production lines will be compared with the actual line using simulation runs again. The evaluation and improvement of the production line will be presented according to output, current content, average time, operator, production capacity, and smoothing index. The determination of the best production path between the actual production path with the production path of the simulation results is seen based on the value of the variables that have been determined.

\section{Result and discussion}

Check of initial line balancing begins with precedence diagram of process sequence. Process sequence of fan production at each work station can be seen at Table 1 .

Table1. Process sequence of fan production.

\begin{tabular}{|c|l|r|r|}
\hline No. & \multicolumn{1}{|c|}{ Work Station } & \multicolumn{1}{c|}{$\begin{array}{c}\text { Predecessor } \\
\text { Work } \\
\text { Station }\end{array}$} & \multicolumn{1}{c|}{$\begin{array}{c}\text { Process } \\
\text { Time } \\
\text { (second) }\end{array}$} \\
\hline 1 & $\begin{array}{l}\text { Installation of lower } \\
\text { footprint }\end{array}$ & - & 142,73 \\
\hline 2 & $\begin{array}{l}\text { Installation of dynamo } \\
\text { and house cover dynamo }\end{array}$ & - & 44,10 \\
\hline 3 & $\begin{array}{l}\text { Installation of front } \\
\text { casing and hinge }\end{array}$ & $-2,3$ & 101,16 \\
\hline 4 & $\begin{array}{l}\text { Installation of dynamo } \\
\text { on front casing }\end{array}$ & 4 & 427,16 \\
\hline 5 & $\begin{array}{l}\text { Installation of button } \\
\text { casing, button, cable } \\
\text { connection and } \\
\text { soldering }\end{array}$ & 5 & 266,66 \\
\hline 6 & $\begin{array}{l}\text { Testing, house dynamo } \\
\text { installation, sticker } \\
\text { installation, andplastic } \\
\text { nuts installation }\end{array}$ & 6 & 463,43 \\
\hline 7 & $\begin{array}{l}\text { Installation ofback } \\
\text { casing }\end{array}$ & 7 & 103,20 \\
\hline 8 & Testing of Propeller & 1,8 & 862,02 \\
\hline 9 & Packaging & 2502,32 \\
\hline & \multicolumn{1}{|c|}{ Total } & & \\
\hline
\end{tabular}

Based on the above process sequence, a precedence diagram of fan production process shown in Fig. 1.

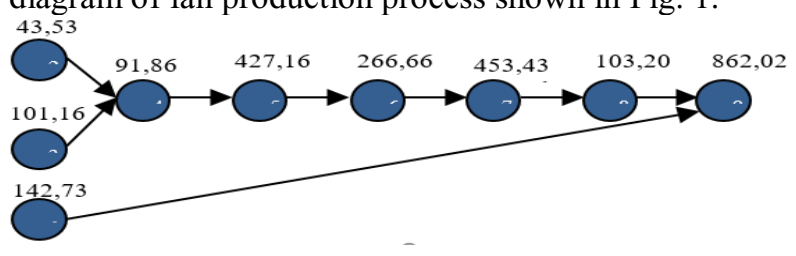

Fig. 1. Precedence diagram of fan production. 
Furthermore, a production line model is made using software. The software used in translating production line system of fan is ProModel 7.5 Student Version. Translation of the fan production trajectory model with ProModel 7.5 as shown in Fig. 2.

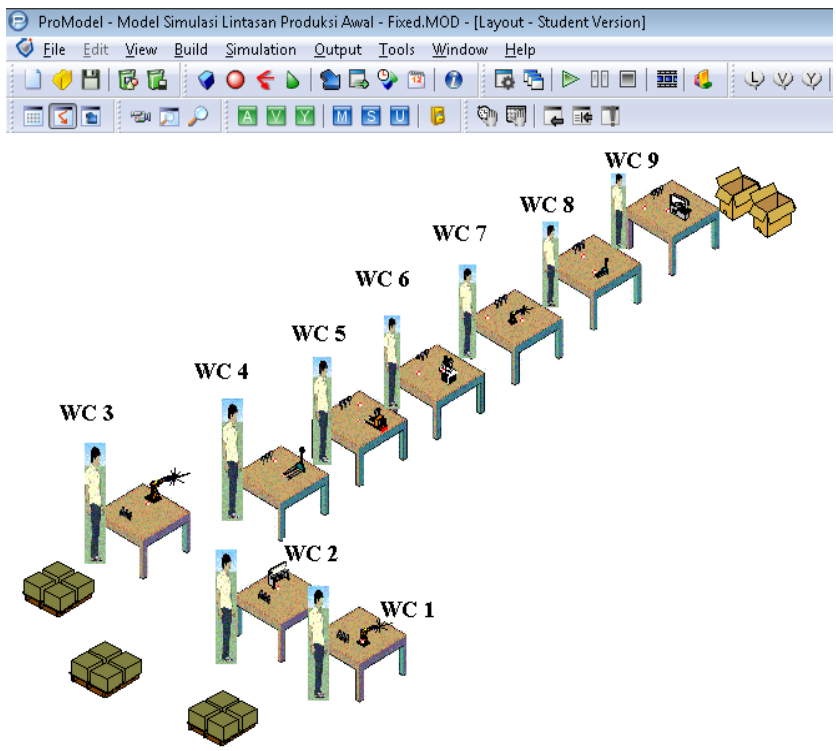

Fig. 2. Production line model of fan production.

After obtaining the standard time of each work station, calculated smoothness index of the fan production line as follows.

$$
\begin{aligned}
& \mathrm{SI}=\sqrt{\sum_{i=1}^{k}\left(S T_{\text {max }}-S T_{i}\right)^{2}} \\
& \mathrm{SI}=1907,25
\end{aligned}
$$

Smoothness index of fan production lineis 1907,25. This indicates that performance of the initial fan production line is still not good soit needs to be improved. Improvements were made by determining alternatives to the model system of early fan production line. The determination of alternatives is done with the basic rules of line balancing production that split the task and share the task. Alternative 1 and alternative 2 simulation models can beseen in Fig. 3 .

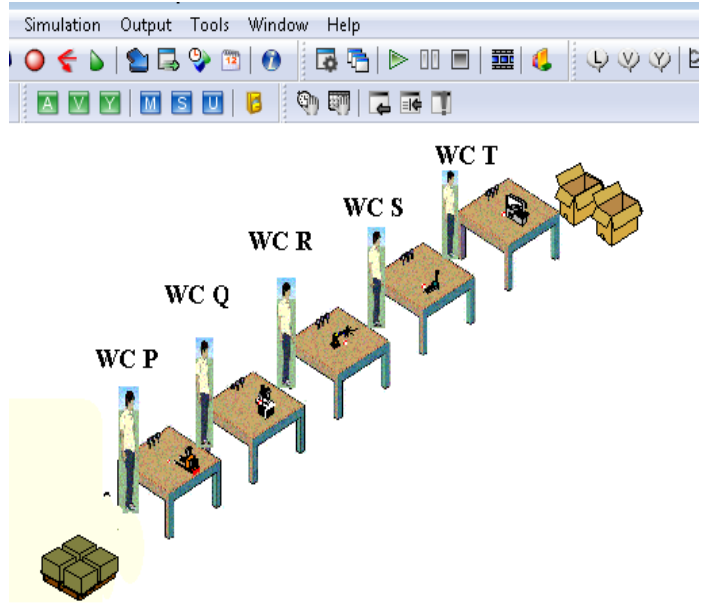

Fig. 3. Production line model alternative 1 and alternative 2 .

Alternative 3 of model simulation can be seen on Fig. 4.

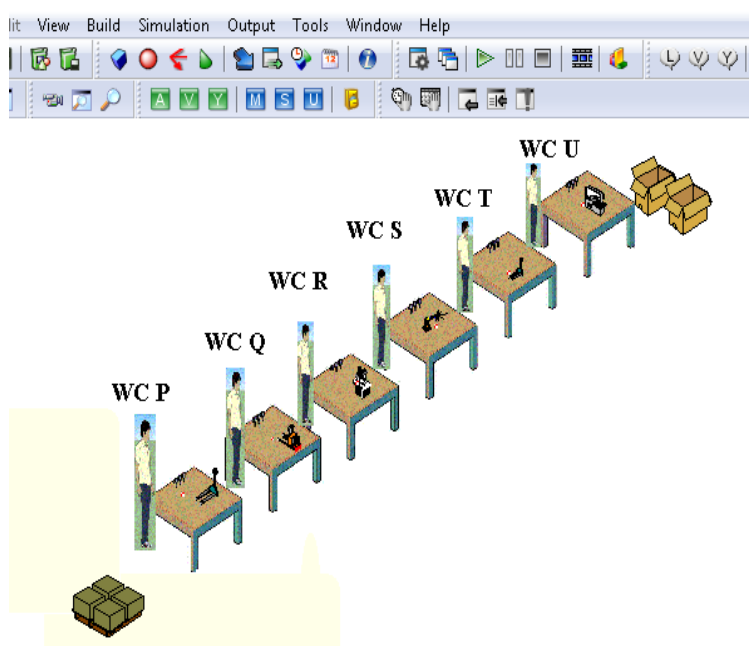

Fig. 4.Alternative 3 of production line model.

Furthermore, the best alternative model is determined by seeing into performance factors of the production line, ie, CurrentContent (CC), Output (O), Average Time in operation (AT), Smoothness Index (SI), number of operators, and work capacity of performance recapitulation of each model.

Table 2. Performance recapitulation of each model.

\begin{tabular}{|l|r|r|r|r|r|r|}
\hline \multirow{2}{*}{ Model } & \multicolumn{6}{|c|}{ Performance Factors } \\
\cline { 2 - 7 } & $\begin{array}{c}\text { Current } \\
\text { Content (unit) }\end{array}$ & $\begin{array}{c}\text { Output } \\
\text { (unit) }\end{array}$ & $\begin{array}{c}\text { Average Time } \\
\text { (minute) }\end{array}$ & $\begin{array}{c}\text { Smoothing } \\
\text { Index }\end{array}$ & $\begin{array}{c}\text { Operator } \\
\text { (person) }\end{array}$ & $\begin{array}{c}\text { Production } \\
\text { Capacity (unit/hour) }\end{array}$ \\
\hline Actual Production Line & 9 & 33 & 33,72 & 1907,25 & 9 & 5,46 \\
\hline Alternative 1 & 4 & 47 & 33,72 & 263,74 & 5 & 7,70 \\
\hline Alternative 2 & 3 & 48 & 33,72 & 286,32 & 5 & 8,05 \\
\hline Alternative 3 & 1 & 50 & 33,72 & 259,48 & 6 & 9,24 \\
\hline
\end{tabular}

Based on Table. 2, the overall alternative model is better than the actual production line model. Alternative models 1 and 2 has many advantageous performance such a slow number of operators ( 5 people). However, the alternative model 3 has many advantageous performance in 4 things, the lowest current content (1unit), the highest output (50 units), the lowest smoothness index (259.48) and the highest production capacity (9.24 units / hour). Alternative average time in operation factor 3 is not significantly different from the other models, which is only 0.01 minutes or 0.6 seconds. Therefore, the alternative model 
of the best production lineis the alternative model 3 . Results of this study clarify previous studies which states that assembly line using simulation is able to overcome the problem of stacking at certain work stations that cause of bootleneck [13]. Simulation is able to analyze the performance of the alternatives produced by using the computer without having to wait for application on the real system [7,9].

\section{Conclusions}

Line balancing is done to balance workload between workstations so bottleneck can be avoided. The use of simulations is done to provide ease in analyzing the performance of the alternatives produced without having to wait to be applied in real system. Using the simulation, it is found that the overall alternative model is better than the actual production line model for all characteristics, ie content content, average time, output, smoothing index, number of operator, and production capacity.

Authors would like to thank to Universitas Sumatera Utara forfunding the financial support for publishing this paper.

\section{References}

1. S. Buyuksaatci, F. Tuysuz, K. Bilen, Balancing and Simulation of Assembly Line in an LCD Manufacturing Company, IEEE 15, (2015)

2. M. Kayar, M. Akalin, Comparing Heuristic and Simulation Methods Applied to the Apparel Assembly Line Balancing Problem, Fibres \& Textiles in Eastern Europe J. 24, 116 (2016)

3. E. Erel, Sabuncuoglu I, B.A. Aksu, Balancing of UType Assembly Systems Using Simulated Annealing, International Journal of Production Research 39, 13 (2001)

4. B. Das, J.M. Sanchez-Rivas, A. Garcia-Diaz, C.A. MacDonald, A computer simulation approach to evaluating assembly line balancing with variable operation times, Journal of Manufacturing Technology Management 21, 7 (2010).

5. K. Syahputri, R. M Sari, Anizar, I. Rizkya, J. Leviza, I. Siregar, Improving Assembly Line Balancing Using Moodie Young Methods on Dump Truck Production, IOP Conf. Ser.: Mater. Sci. Eng, 288 (2018)

6. W. Grzechca, Manufacturing in Flow Shop and Assembly Line Structure, Int. J. MMM 4, 1 (2016)

7. Averill M L, W. David K, Simulation modeling and analysis (McGraw-Hill, USA, 1982)

8. D.Kitaw, A. Matebu, S. Tadesse, ALBUSTIGMF, EEA. J, 27 (2010)

9. A. Hafezalkotob, H. Ketabian, H. Rahimi, Balancing the Production Line by the Simulation and Statistics Techniques: A Case Study, Research Journal of Applied Sciences, Engineering and Technology7, 4 (2014)
10. S. Masood, Line balancing and simulation of an automated production transfer line, Assembly Automation 26, 1(2006)

11. H. Wang, H. Wang, H. Zhang, Study of assembly line dynamic balancing based on simulation, International Technology and Innovation Conference (ITIC), (2009)

12. M. Jamil, N. Mohd. Razali, Simulation of Assembly Line Balancing in A Automotive Component Manufacturing, IOP Conf. Series: Materials Science and Engineering, 114 (2016)

13. S. Kurşun Bahadır, Assembly Line Balancing in Garment Production by Simulation, InTech, (2011)

14. F. Robert J, R. B. Case, Operations and Supply Management: The Core (McGraw-Hill, New York 2008)

15. J. Banks, Jerry, J. S. Carson, B. L Nelson, D. Nicol, Discrete-Event System Simulation. Fourth Edition, (Prentice Hall, USA, 2004)

16. F. R. Jacobs, R. B. Case, Operation and Supply Management : The Core, (McGraw-Hill, NewYork, 2008) 